\title{
EKSISTENSI HUKUM JAMINAN DALAM PROGRAM PEMULIHAN EKONOMI NASIONAL (PEN) PADA MASA PANDEMI COVID-19
}

\author{
Elisatin Ernawati \\ Magister Kenotariatan Universitas Islam Malang \\ Email : elisatin@unisma.ac.id

\begin{abstract}
Ahmad Syaifudin
Fakultas Hukum Universitas Islam Malang, email : ahmad_syaifudin@unisma.ac.id
\end{abstract}

\begin{abstract}
Abstrak
Pelaksanaan program pemerintah dalam upaya Pemulihan Ekonomi Nasional sebagaimana yang telah dirumuskan dalam PP No. 23 / 2020, telah memasukkan program penjaminan sebagai salah satu skema yang berkontribusi dominan dalam keberhasilan program. Eksistensi hukum jaminan menjadi dipertanyakan sejauh mana dapat mengambil peran termasuk partisipasi Notaris dalam menjalan peran dan wewenangnya. Dalam penelitian ini penulis menggunakan metode penelitian yuridis normatif dengan memakai pendekatan konsep (conceptual approach), perundang-undangan (Statute Approach) dan pendekatan kasus (Case Approach). dari penelitian dapat disimpulkan bahwa jaminan dalam prespektif hukum jaminan membagi dalam bentuk jaminan kebendaan dan penanggungan telah berkembang dengan sangat cepat. Jaminan kebendaan yang membatasi nilai obyek jaminan berkembang sesuai dengan regulasi, sedangkan jaminan penanggungan (jaminan personal, korporasi) berkembang sesuai dengan perkembangan ekonomi dan bisnis. Keberadaan Notaris dalam kondisi apapun tetap mengambil peran sentral sesuai dengan tugas dan kewenangan terutama dalam merumuskan perjanjian pokok dan tambahan sebagai akta otentik yang mengikat para pihak.
\end{abstract}

Kata Kunci: PEN, Hukum Jaminan, Notaris

\section{Abstract}

Implementation of government programs in efforts to restore the National Economy as formulated in PP. 23/2020, has included the guarantee program as one of the schemes that have contributed dominantly to the success of the program. The existence of guarantee law becomes questionable to what extent it can take a role, including the participation of a notary in carrying out its functions and its authority. In this study the authors used a normative juridical research method using a conceptual 
approach, statutory approach and a case approach. From the research it can be concluded that guarantees in the perspective of security law divides into the form of property guarantees and coverage has grown very rapidly. Material guarantees that limit the value of the object of guarantee develop in accordance with regulations, while security guarantees (personal, corporate guarantees) develop according to economic and business developments. The existence of a Notary in any condition still plays a central role in accordance with the duties and authorities, especially in formulating the main and additional agreements as authentic deeds that bind the parties.

Keywords: PEN, Guarantee Law, Notary

\section{PENDAHULUAN}

Memasuki Era Pandemi yang sudah berjalan hampir genap 1 (satu) tahun, masih belum terlihat apakah kehidupan normal akan pulih seperti sedia kala atau bahkan harus terus bertahan dengan kondisi seperti saat ini. Pertimbangan-pertimbangan bahwa kehidupan harus terus berlangsung dan semua tidak boleh kalah atau mengalah dengan kondisi pandemik ini, membuat semua harus berinovasi dan melakukan terobosan-terobosan dalam seluruh lini kehidupan. Program bidang kesehatan selain terus sosialisasi tentang penjagaan diri program vaksinasi juga dijalankan. Bidang bidang ekonomi program pemulihan dan pengembangan ekonomi dengan kondisi baru juga terus dikembangkan.

Khususnya dalam bidang ekonomi Pemerintah telah merumuskan program Pemulihan Ekonomi Nasional (PEN). Pelaksanaan Program PEN ini tentunya perlu dikawal agar semua program yang dirumuskan tepat sasaran dan berdaya guna. Kepala Badan Kebijakan Fiskal Kementrian Keuangan RI sekaligus Dosen FEB Universtias Indonesia, Febrio N. Kacaribu dalam diskusi public oleh Prodeep Institute (sabtu, 27/6/2020) menuturkan dampak Covid 19 terhadap perekonomian Indonesia memberi ancaman pada sisi komsumsi. Pertumbuhan Q1-2020 menunjukkan konsumsi termasuk rumah tangga sebesar 2,84\%. Lembaga Non Profit Rumah Tangga (LNPRT) sebesar $-4,91 \%$, pemerintah 3,74\%, pembentukan Modal Tetap Bruto (PMTB) 1,07\% dan Net Ekspor 0,45\%. Sector-sektor utama penopang perekonomian melambat pada 3 sektor, pertama primer $0.18 \%$ year of year, meliputi pertanian dan pertambangan, kedua sekunder year of year terdiri dari manufaktur, listrik, gas, air dan konstruksi. Ketiga, tersier 4,62\% year of year, seperti perdagangan transportasi dan Gudang, infokom, jasa keuangan, asurandi dan jasa lainnya. Di saat bersamaan Febrio juga menyampaikan bahwa pemerintah mengeluarkan kebijakan dukungan fiskal untuk penanganan Covid-19 berjumlah Rp 695,2 triliun, 
yang dialokasikan untuk kesehatan sebesar Rp 87,55 triliun, perlindungan social Rp 203,90 triliun, UMKM Rp 123,46 triliun, instentif usaha Rp 120,61 triliun, pembiayaan korporasi Rp 53,57 triliun, dan sector K/L dan Pemda sebesar Rp 106.11 triliun. Selain itu, biaya PEN berjumlah 607,65 triliun dan dipergunakan untuk sisi permintaan sebssar Rp 205.20 triliun dan sisi penawaran sebesar Rp 402,45 triliun. ${ }^{1}$

Prioritas utama program PEN adalah bertumpu pada UMKM dalam pemulihan ekonomi nasional. Program PEN diharapkan menjadi faktor pengungkit perekonomian di kuartal ketiga dan keempat tahun 2020, terang Menko Perekonomian Herlangga Hertarto ${ }^{2}$. Menko menyampaikan, sampai dengan 31 Mei 2020 terdapat 13 penyalur KUR yang telah melaporkan pelaksanaan kebijakan KUR terkait Covid-19. Rincian kebijakan KUR pada masa Covid-19 yang diberikan kepada penerima KUR adalah sebagai berikut :

1. Tambahan subsidi bunga KUR diberikan kepada 1.449.570 debitur dengan bakli debet Rp 46.1 triliun

2. Penundaan angsuran pokok paling lama 6 bulan diberikan kepada 1.395.009 debitur dengan baki debet Rp 40.7 triliun

3. Relaksasi KUR, berupa :

a. Perpanjangan jangka waktu diberikan kepada 1.393.024 debitur dengan baki debet $\mathrm{Rp} 39.9$ triliun

b. Belum ada laporan mengenai penambahan limit plafon Sebagaimana ditentukan impelementasi program PEN tersebut dilakukan pemerintah melalui skema modalitas sebagai berikut :

1. Penempatan Dana ke Perbankan dengan tujuan memberikan dukungan likuiditas kepada perbankan yang melakukan restrukturisasi kredit/pembiayaan dan/atau memberikan tambahan kredit/pembiayaan modal kerja

2. Penjaminan Kredit Modal Kerja kepada Badan Usaha Milik Negara (BUMN) atau melalui PT. Jamkrindo/PT. Askrindo

3. Penyertaan Modal Negara yang memperbaiki struktur permodalan BUMN dan/atau anak perusahaan BUMN yang terdampak Covid-19 dan meningkatkan kapasitas usaha BUMN dan/atau anak perusahaan BUMN temasuk melaksanakan penugasan khsusu oleh Pemerintah dalam melaksanakan Program PEN.

4. Investasi Pemerintah sesuai dengan peraturan Perundang-undangan

\footnotetext{
${ }^{1}$ https://www.feb.ui.ac.id/blog/2020/06/30/febrio-n-kacaribu-program-pemulihanekonomi-nasional-agar-tepat-sasaran-dalam-diskusi-publik-prodeep-institute/, diunduh 28 Januari 2021

${ }^{2}$ https://ekon.go.id/info-sektoral/17/89/percepat-pemulihan-ekonomi-nasionalpemerintah-luncurkan-penjaminan-kredit-modal-kerja-umkm, diunduh 28 Januari 2021
} 
5. Selain itu, Pemerintah juga dapat melakukan kebijakan untuk memberikan dukungan bagi pelaku Usaha melalui belanja negara sesuai dengan ketentuan peraturan perundang-undangan.

Lebih jelasnya berikut disampaikan, tabel skema Perlindungan dan Pemilihan Ekonomi UMK ${ }^{3}$.

\begin{tabular}{|c|c|}
\hline Skema & $\begin{array}{l}\text { Uraian } \\
\end{array}$ \\
\hline Subsidi bunga & $\begin{array}{l}\text { Kepada UMK selama enam bulan sebesar Rp } \\
35,29 \text { triliun di perbankan serta perusahaan } \\
\text { pembiayaan dan lembagi penyalur kredit } \\
\text { pemerintah }\end{array}$ \\
\hline Penjaminan Modal Kerja & Untuk modal kerja sebesar Rp 1 Triliun \\
\hline Pembayaran Investasi & $\begin{array}{l}\text { Kepada koperasi melalui Lembaga Pengelola } \\
\text { Dana Bergilir (LPDB) kementrian koperasi } \\
\text { dan UKM sebesar Rp } 1 \text { Triliun }\end{array}$ \\
\hline Penempatan Dana & $\begin{array}{l}\text { Di Perbankan untuk restrukturisasi sebanyak } \\
\text { Rp } 78,78 \text { triliun }\end{array}$ \\
\hline Belanja Imbal Jasa Penjaminan (LIP) & Sebesar Rp 5 Triliun \\
\hline PPh Final UMK & $\begin{array}{l}\text { Tarif Pajak yang tanggung pemerintah (DTP) } \\
\text { sebesar RP 2,4 triliun }\end{array}$ \\
\hline Bantuan Modal Produktif & $\begin{array}{l}\text { Bantuan sebesar Rp 2,4 juta per pelaku usaha } \\
\text { untuk tambahan modal kerja dengan target } 12 \\
\text { juta penerima (tahap awal } 9.1 \text { juta penerima) }\end{array}$ \\
\hline
\end{tabular}

Sumber Kompas (2020)

Menariknya dari ilustrasi dan gambaran diatas, dalam konteks pelaksanaan program PEN yang dirumuskan oleh Pemerintah memasukkan skema Penjaminan dalam program PEN sebagai salah satu upaya mitigasi resiko agar program yang dilakukan dapat dilakukan sesuai dengan yang telah ditetapkan dan potensi penyaluran kredit yang mengalami kegagalan dalam proses pengembalian (non performance loan) sebagai bagian program pemulihan risiko keuangan.

Pemahaman tentang perlunya instrument penjaminan sebagai salah satu cara untuk melakukan perlindungan keberlangsungan program PEN, memunculkan permasalahan tersendiri yaitu, Instumen penjaminan apakah yang digunakan dan atau dilakukan oleh pemerintah dalam mendukung pelaksanaan program PEN dimasa pandemic Covid-19 ini dan bagaimana notaris menjaga eksistensinya dalam program in.

\section{METODE PENELITIAN}

Tulisan ini disusun dengan menggunakan metode penelitian yuridis normative, jenis penelitian yang dilakukan untuk menemukan aturan 
hukum, prinsip-prinsip hukum, teori, doktrin hukum yang mampu menjawab isu hukum khususnya untuk preskripsi apa yang sebaiknya. Pendekatan yang digunakan dalam tulisan ini yaitu conceptual approach, pendekatan yang lebih menekankan pada substansi konsep (memahami istilah-istilah dalam permasalah hukum jaminan) atas suatu proposisi untuk menempatkan konsep itu pada tempat yang memang diharapkan, statute approach pendekatan peraturan perundang-undangan yang relevan dengan permasalahan yang dibahas. Case approach pendekatan kasus yang muncul dan terjadi dalam lingkup pembahasan terutama yang saat ini sedang berjalan khususnya dalam penanganan pemulihan ekonomi dimasa Covid$19 .^{4}$

Bahan hukum yang digunakan adalah : 1) bahan hukum primer, KUHPerdata, UU No. 4 tahun tahun 1996 tentang Hak Tanggungan,, No. 42 tahun 1999 tentang Fiducia. UU No. 2 tahun 2014 tentang Undang-Undang Jabatan Notaris, UU Nomor 1 Tahun 2016 Tentang Penjaminan dan Nomor 2 Tahun 2020 Tentang Penetapan Peraturan Pemerintah Pengganti Undangundang Nomor 1 Tahun 2020 Tentang Kebijakan Keuangan Negara Dan Stabilitas Sistem Keuangan Untuk Penanganan Pandemi Corona Virus Disease 2019 (Covid- 19) dan/atau Dalam Rangka Menghadapi Ancaman Yang Membahayakan Perekonomian Nasional dan / atau Stabilitas Sistem Keuangan Menjadi Undang-Undang berikut dengan PP No. 23/2020 dan PMK No. 71/2020. 2) bahan sekunder berupa buku-buku, jurnal-jurnal dan 3) tersier, dari beberapa akses media (internet) yang relevan dengan permasalahan dalam tulisan ini. Dalam tulisan ini Teknik pengumpulan bahan hukum dilakukan dengan cara melakukan identifikasi terhadap bahan hukum primer dan sekunder yang relevan dengan permasalahan untuk kemudian diinventarisir dan diklasifikasikan sesuai dengan kedudukan bahan hukum. Sedangkan Teknik analisis bahan hukum dilakukan dengan jalan preskriptif (content analysis) dengan pola deskriptif deduktif analisis untuk menemukan jawaban yang diharapkan.

\section{PEMBAHASAN}

\section{A. Eksistensi Lembaga Jaminan di Indonesia}

Jaminan yang merupakan terjemahan istilah zekerheid atau coutie yaitu kemampuan debitur untuk memenuhi atau melunasi perutanganya kepada kreditur yang dilakukan dengan cara menahan benda tertentu yang bernilai ekonomis sebagai tanggungan atas pinjaman atau uang yang diterima debitur terhadap krediturnya. Arti jaminan menurut Undangundang nomor 14 tahun 1967 diberi istilah "agunan" atau "tanggungan",

${ }^{4}$ Peter Mahmud Marzuki, 2016, Penelitian Hukum Edisi Revisim Cetakan ke 12, Jakarta : Prenada Media Group .hlm 57 dan 119 
sedangkan "jaminan" menurut Undang-undang nomor 7 tahun 1992 yang telah dirubah dengan Undang-undang nomor 10 tahun 1998 tentang Perbankan, diberi arti lain yaitu "keyakinan atas I'tikad dalam kemampuan serta kesanggupan nasabah debitur untuk melunasi utangnya atau mengembalikan pembiayaan dimaksud sesuai dengan diperjanjikan". Sehubungan dengan penjelasan pasal 8 (1) Undang-undang Perbankan menyatakan bahwa "untuk mengurangi resiko tersebut, jaminan pemberian kredit atas pembiayaan berdasarkan prinsip Syariah dalam arti keyakinan atau kemampuan dan kesanggupan Nasabah, debitur untuk melunasi kewajibannya sesuai dengan diperjanjikan merupakan faktor penting yang harus diperhatikan oleh bank". Karena hal tersebut agar diperoleh keyakinan, sebelum memberikan kredit, bank harus melakukan penilaian yang saksama terhadap watak, kemampuan, modal, agunan dan prospek usaha dari Nasabah Debitur. Istilah "Agunan" dalam UU Perbankan diartikan "Agunan adalah jaminan tambahan yang diserahkan nasabah debitur kepada bank dalam rangka pemberian fasilitas kreditr dan pembiayaan berdasarkan prinsip Syariah".Artinya istilah "agunan" yang diterjemahkan juga dalam istilah collateral merupakan bagian dari istilah "jaminan" dan dalam hal ini diartikan lebih luas tidak hanya berkaitan dengan "barang" tetapi berkaitan dengan character, capacity, capital, dan condition of economy dari nasabah bersangkutan. ${ }^{5}$

Djuhaendah Hasan mengemukan bahwa pertimbangan dan penilaian terhadap character, capacity, capital, dan condition of economy debitur tanpa memberikan tekanan kepada collateral memang dapat membantu para pengusaha yang menjalankan usaha dengan prospek usaha yang baik dan dalam kondisi perusahaanya yang sehat dan berjalan dengan baik, tetapi akan menjadi masalah bagi pihak bank, apabila dalam perusahaan debitur tersbut tidak berjalan mulus sebagaiman yang telah dinilai semula oleh pihak bak. Ini merupakan satu dilemma disatu sisi bank harus membantu golongan ekonomi lemah, namun pada sisi lain yang melindungi pihak bank sebagai kreditur. Begitu tingginya risiko yang dihadapi pihak bank sebagai kreditur menjadikan jaminan sebagai instrument yang digunakan untuk langkah preventif mitigasi risiko bila debitur tidak dapat meyakinkan bank/kreditur. Dalam kaitan jaminanya pihak bank, selain meminta jaminan pokok juga dapa meminta jaminan tambahan kepada calon debiturnya. ${ }^{6}$ Senada dengan itu Mariam Darus Badrulzaman merumuskan jaminan sebagai suatu tanggungan yang diberikan oleh seorang debitur dan atau hlm. 66

${ }^{5}$ Rachmadi Usman, Hukum Jaminan Keperdataan, 2016, Jakarta, Sinar Grafika,

${ }^{6}$ Djuhaedah Hasan, Hak Tanggungan atas tanah dan implikasinya terhadap benda-benda yang berkaitan dengan tanah, 1996, Bandung, Citra Aditya Bakti hlm.2010 
pihak ketiga kepada kreditur untuk menjamin kewajibannya dalam suatu perikatan. $^{7}$

Dari perumusan jaminan diatas, dapat disimpulkan bahwa jaminan itu suatu suatu tanggungan yang dapat dinilai dengan uang, yaitu berupa kebendaan tertentu yang diserahkan debitur kepada kreditur sebagai akibat dari suatu hubungan perjanjian utang piutang atau perjanjian lain. Kebendaan tertentu diserahkan debitur kepada kreditur dimaksudkan sebagai tanggungan atas pinjaman atau fasilitas kredit yang diberikan kreditur kepada debitur sampai debitur melunasi pinjaman tersebut. Dengan kata lain jaminan disini berfungsi sebagai sarana untuk menjamin pemenuhan jaminan atau utang debitur seandainya wanprestasi sebelum sampai jatuh tempo pinjaman atau utangnya berakhir. ${ }^{8}$ Jaminan sendiri yang berlaku di Indonesia dapat digolongan 2 macam, yaitu:

1. Jaminan materiil (kebendaan), yaitu jaminan kebendaan dan

2. Jaminan Imateriil (perorangan), yaitu jaminan perorangan

Jaminan kebendaan mempunyai ciri-ciri "kebendaan" dalam arti memberikan hak mendahulu diatas benda-benda tertentu dan mempunyai sifat melekat dan mengikuti benda yang bersangkutan "droit de suite". Sedangkan jaminan perorangan tidak memberikan hak mendahuli atas benda-benda tertentu tetapi hanya dijamin oleh harta kekayaan seseorang lewat orang yang menjamin pemenuhan perikatan yang bersangkutan (Hasil Seminar Badan Pembinaan Hukum Nasional Yogjakarta, pada tanggal 20 30 Juli 1977. Sri Soedewi Maschoen Sofwan, mengemukan pengertian Jaminan materiil (kebendaan) dan jaminan Imateriil (Perorangan) adalah "Jaminan yang berupa hak mutlak suatu benda, yang mempunyai ciri-ciri mempunyai hubungan langsung atas benda tertentu, dapat dipertahankan terhadap siapapun, selalu mengikuti bendanya dan dapat dialihkan. Sedangkan jaminan imateriil (perorangan) adalah jaminan yang menimbulkan hubungan langsung pada perorangan tertentu, hanya dapat dipertahankan terhadap debitur tertentu, terhadap harta kekayaan debitur umumnya"

Konteks Perjanjian jaminan, merupakan perjanjian tambahan (Accecoir), karena adanya perjanjian tersebut tergantung dari perjanjian pinjaman uang (Perjanjian Kredit) yang merupakan perjanjian pokoknya. Tanpa adanya perjanjian Pinjam Uang (Perjanjian kredit) atau perjanjian lainnya yang menyebabkan timbunya utang maka tidak mungkin ada

\footnotetext{
${ }^{7}$ Mariam Darus Badrulzaman, Beberapa permasalahan hukum hak jaminan, 2000, Jurnal Hukum Bisnis Volume 11, Jakarta: Yayasan Pengembangan Hukum Bisnis

${ }^{8}$ Rachmadi Usman, op.cit, hlm. 69

${ }^{9}$ Sri Soedewi Masjchoen Sofwan, Hukum Jaminan di Indonesia, 1985, Jakarta, BPHN. hlm. 46
} 
perjanjian jaminan dan jika perjanjanjian jaminan tersebut hapus dengan sendirinya demikian hukum perjanjian jaminan juga turut hapus. ${ }^{10}$ Menurut penjelasan pasdal 10 (1) UUHT, perjanjian pokok yang menimbulkan utang itu dapat dibuat dengan akta dibawah tangan atau dengan akta otentik, bergantung kepada ketentuan hukum yang mengatur materi perjanjian. Perjanjian pokok dapat dibuat dibawah tangan atau dengan akta otentik ${ }^{11}$

Dari uraian diatas, maka dapat dikemukan unsur-unsur yang tercantum pada jaminan materiil yaitu : 1) hak mutlak atas suatu benda, 2) cirinya mempunyai hubungan langsung atas benda tertentu, 3) dapat dipertahankan terhadap siapapun, 4) selalu mengikuti bendannya, dan 5) dapat dialihkan kepada pihak lainnya, jaminan kebendaan ini digolongkan menjadi 5 macam berbentuk : 1) Gadai (pand) diatur dalam Bab 20 buku II BW, 2) hipotek, diatur dalam Bab 21 Buku II BW, 3) Hak Tanggungan, diatur dalam UU No. 4 tahun 1996 tentang Hak Tanggungan, 4) Jaminan Fiducia, diatur dalam UU No. 42 tahun 1999 tentang Fiducia.

Sedangkan unsur jaminan perorangan yaitu : 1) mempunyai hubungan langsung pada orang tertentu, 2) hanya dapat dipertahankan terhadap debitu tertentu dan, 3) terhadap harta kekayaan debitur umumnya. Jaminan perorangan ini diklasifikasikan dalam 3 bentuk : 1) Penanggung (borg) adalah orang lain yang dapat ditagih, 2) tanggung menanggung yang serupa dengan tanggung renteng dan, 3) perjanjian garansi. ${ }^{12}$

Gambaran Hukum jaminan di Indonesia, secara umum adalah sebagaimana berikut :

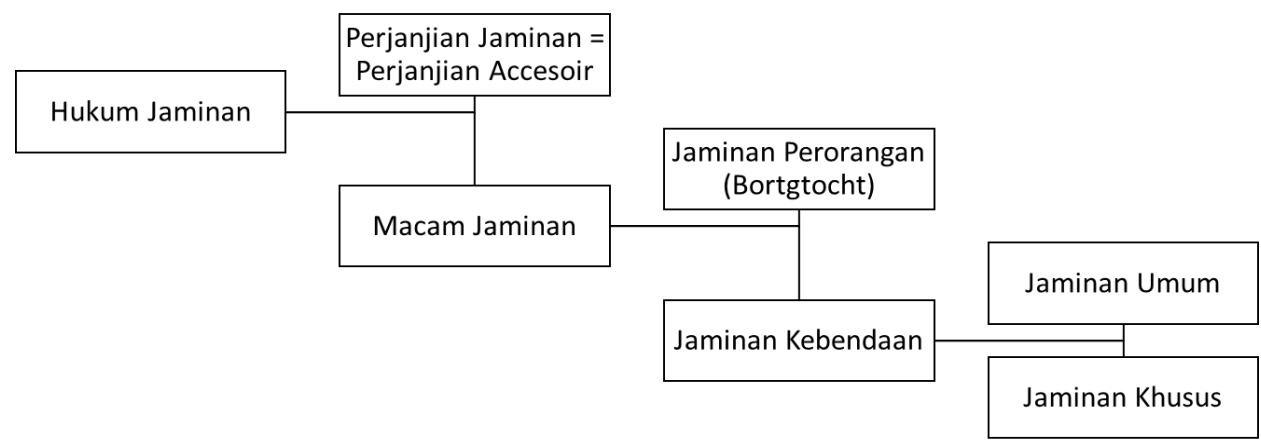

10 Alwesius, Hukum Jaminan dalam teori dan Praktek serta Implikasi Permen ATR No. 9 tahun 2019, 2019, Malang Sosialisasi Permen ATR No.. 9 tahun 2019, IPPAT Malang

${ }^{11}$ SR. Remy Syahdeini, Hak Tanggungan asas-asas ketentuan-ketentuan Pokok dan Masalah yang dihadapi oleh Perbankan (Suatu kajian mengenai Undang-undang Hak Tanggungan), 1999, Bandung, Alumni, hlm. 51

12 Salim HS, Perkembangan Hukum Jaminan di Indonesia, 2019, Depok, Rajagrafindo Persada. hlm. 25 
Gambar 1. Lingkup umum hukum jaminan

Penjelasan dari gambar diatas dapat diperoleh dari ketentuan yang tertuang dalam KUHPerdata pasal 1131 yang disebut dengan prinsip kesamaan kedudukan Kreditur (Paritas Criditorium) dan pasal 1132 KUHPerdata yang disebut dengan dengan prinsip Pari Passu Prorate Perte. ${ }^{13}$ Semua kreditur mempunyai hak yang sama atas harta debitur, kecuali ada alasan-alasan yang sah untuk didahulukan sebagaimana yang ditentukan dalam pasal 1133 dan selanjutnya. Konseksensinya muncul hak Istimewa, artinya bahwa ketentuan pasal tersebut menentukan terdapat hak untuk didahulukan diantara orang-orang berpiutang (kreditur) dalam hal ini disebut adalah Gadai dan Hipotik. Dengan perkembangan munculnya Hak tanggungan dan Fiducia, maka hak untuk didahulukan diantara para kreditur ditentukan timbul karena "hak istimewa", gadai, fiducia, hipotek dan hak tanggungan. Hak istimewa dapat digambarkan sebagai berikut :

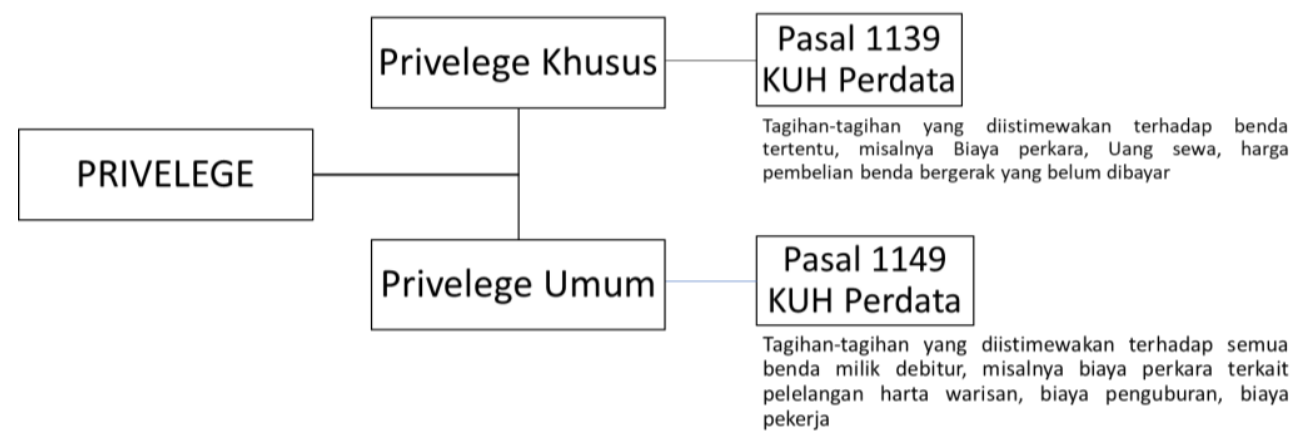

Gambar 2. Jaminan diistimewakan (Privelege)

Selain hak yang diistimewakan jaminan yang bersifat kebendaan diatur sebelumnya dalam KUH Perdata terdapat penyesuaian misalnya tentang Hipotik yang dahulu berlaku juga untuk tanah dengan berlakunya Hak Tanggungan menjadi tidak berlaku dan Hipotik hanya berlaku untuk obyek berupa Kapal Laut. Dalam hal jaminan kebendaan dapat digambarkan sebagai berikut :

${ }^{13}$ Susanti Adi Nugroho, Hukum Kepailitan di Indonesia, 2018, Jakarta, Kencana, hl. 37 


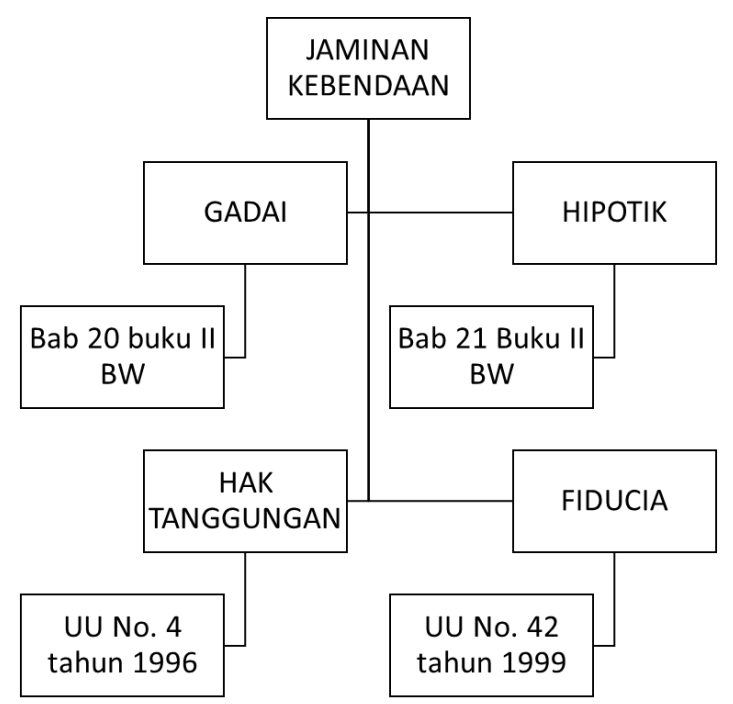

Gambar 3. Jaminan Kebendaan

Sedangkan Jaminan immateriil (Perorangan) diatur dalam pasal 1820 - 1850 KUH Perdata, dikenal dengan istilah penanggungan (borgtocht) pasal $1820 \mathrm{KUH}$ Perdata yaitu suatu persetujuan dengan mana seorang pihak ketiga, guna kepentingan kreditur mengikatkan diri untuk memenuhi perikatannya debitur manakala debitur tidak memenuhi kewajibannya (wanprestasi). Sosok perjanjian jaminan perorangan sesuai letaknya ada pada Buku III BW, maka yang dilahirkan tergolong sebagai hak perorangan atau hak pribadi. Seperti diketahui bahwa obyek perikatan adalah prestasi. ${ }^{14}$ Jaminan Immateriil ini digambarkan sebagai berikut :

${ }^{14}$ Moch. Isnaeni, Pengantar Hukum Jaminan Kebendaan, 2016, Surabaya, Revka Petra Media, hlm 110 


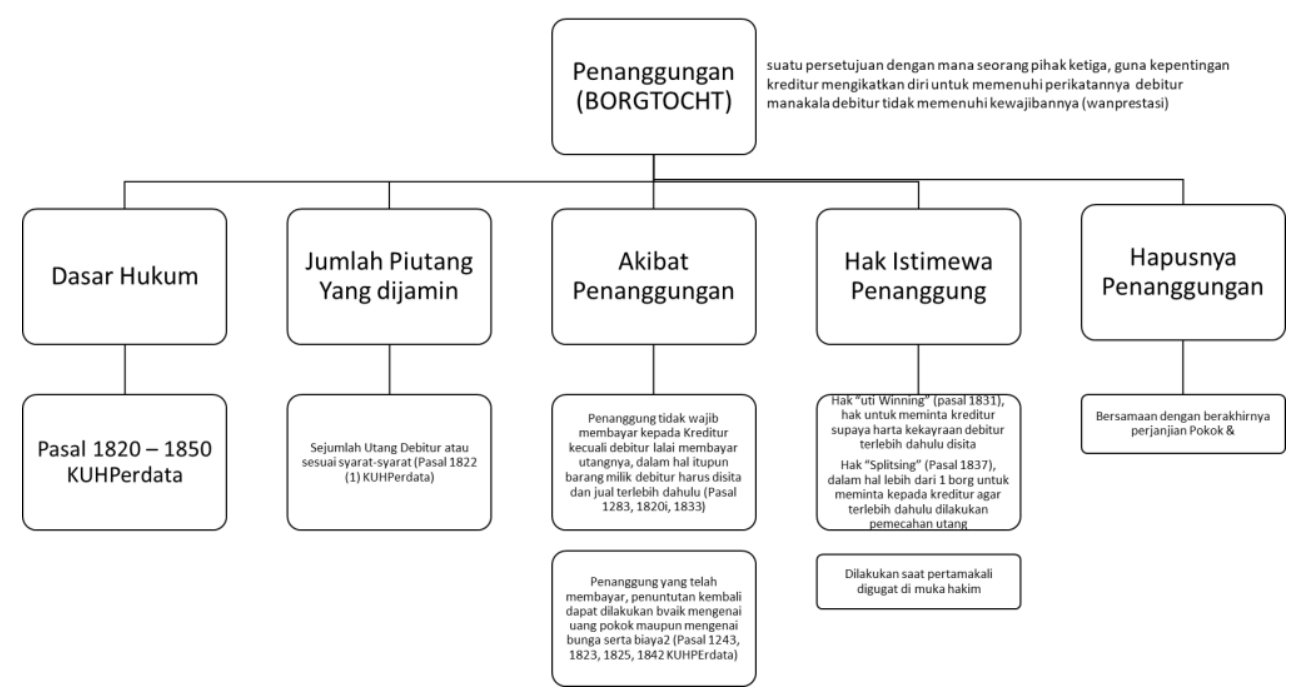

Gambar 4. Jaminan Immateriil (Perorangan) \& hal terkait.

Pasal 1821 "tiada penanggungan, bila tiada perikatan pokok yang sah menurut Undang-undang", akan tetapi orang dapat mengadakan penanggungan dalam suatu perikatan, walaupun perikatan itu dapat dibatalkan dengan sanggahan mengenai diri pribadi debitur, misalnya dalam hal belum cukup umur (KUHPerdata pasal 1331, 1832-30 dan 1847). Jadi jelasnya penanggungan (borgthocht) merupakan accecoir dari perjanjian utang piutang yang merupakan perjanjian pokok, oleh karenanya saat perjanjian pokok berakhir maka perjanjian accecoir ini juga berakhir.

Prakteknya jaminan perorangan ini dilakukan karena memenuhi kepentingan dan tuntutan dari lembaga pembiayaan / kreditur dimana kebutuhan pinjaman/keuangan uang diperlukan oleh debitur melebihi jaminan (Collateral) yang bersifat kebendaan. Jaminan bentuk ini saat ini dapat terjadi dalam bentuk jaminan perorangan (Personal Guarantee) dan atau dalam bentuk Jaminan perusahaan/korporasi (Corporate Guarantee). Pemerintah Indonesia dalam upaya memperkuat lembaga jaminan ini telah merumuskan ketentuannya melalui UU No. 1 tahun 2016 tentang Penjaminan dan dalam ketentuan UU penjaminan tersebut dijelaskan bahwa dalam BAB 1 pasal 1 :

(1) Penjaminan adalah kegiatan pemberian jaminan oleh Penjamin atas pemenuhan kewajiban finansial Terjamin kepada Penerima Jaminan.

(7) Perusahaan Penjaminan adalah badan hukum yang bergerak di bidang keuangan dengan kegiatan usaha utama melakukan Penjaminan.

(11) Penjamin adalah pihak yang melakukan penjaminan. 
(12) Penerima Jaminan adalah lembaga keuangan atau di luar lembaga keuangan yang telah memberikan Kredit, Pembiayaan, Pembiayaan Berdasarkan Prinsip Syariah atau kontrak jasa kepada Terjamin.

(13) Terjamin adalah pihak yang telah memperoleh Kredit, Pembiayaan, Pembiayaan Berdasarkan Prinsip Syariah, atau kontrak jasa dari lembaga keuangan atau di luar lembaga keuangan yang dijamin oleh Perusahaan Penjaminan atau Perusahaan Penjaminan Syariah. Selanjutnya ditentukan secara konkret tujuan Undang-undang penjaminan sebagaimana ditentukan dalam Pasal 3 yaitu untuk:

a. menunjang kebijakan pemerintah, terutama dalam rangka mendorong kemandirian usaha dan pemberdayaan dunia usaha, khususnya usaha mikro, kecil, dan menengah serta koperasi dalam perekonomian nasional;

b. meningkatkan akses bagi dunia usaha, khususnya usaha mikro, kecil, dan menengah serta koperasi dan usaha prospektif lainnya kepada sumber pembiayaan;

c. mendorong pertumbuhan pembiayaan dan terciptanya iklim usaha yang kondusif bagi peningkatan sektor ekonomi strategis;

d. meningkatkan kemampuan produksi nasional yang berdaya saing tinggi dan yang memiliki keunggulan untuk ekspor;

e. mendukung pertumbuhan perekonomian nasional; dan

f. meningkatkan tingkat inklusivitas keuangan nasional.

Perbedaan antar jaminan perorangan dengan jaminan kebendaan adalah : 1) jaminan perorangan terdapat Pihak Ketiga yang menyanggupi untuk memenuhi perikatan debitor bila debitor tidak dapat memenuhi kewajibannya, 2) jaminan kebendaan hanya harta kekayaan debitor sajalah yang dapat dijadikan jaminan bagi pelunasan kredit apabila debitor cidera janji. ${ }^{15}$ Sehingga pengembangan hukum jaminan yang sudah cukup lengkap dengan perluasan dalam bentuk jaminan immaterii/perorangan semakin membuat eksistensi hukum jaminan di Indonesia harus diperhitungkan dan dilakukan dengan memenuhi kaidah-kaidah dan asas - asas yang ditentukan untuk dapat ikut serta mendukung peningkatan pertumbuhan ekonomi di Indonesia.

\section{B. Instrumen Jaminan dalam mendukung pelaksanaan Program PEN}

Jaminan sudah menjadi bagian dari opsi Pemerintah dalam melaksanakan Program PEN yakni : Penyertaan Modal Negara, Penempatan Dana, Investasi Pemerintah dan Penjaminan. Hal ini tercermin dengan diterbitkannya PP No. 23 tahun 2020 oleh Presiden Republik Indonesia

${ }^{15}$ Niken Praseyowati dan Tony Hanoraga - 128 jsh Jurnal Sosial Humaniora, Vol 8 No.1, Juni 2015, hlm. 128 
yang juga merupakan amanat dari Perpu Nomor 1 tahun 2020 dan sudah disahkan menjadi Undang-Undang Republik Indonesia Nomor 2 Tahun 2020 Tentang Penetapan Peraturan Pemerintah Pengganti Undang-undang Nomor 1 Tahun 2020 Tentang Kebijakan Keuangan Negara Dan Stabilitas Sistem Keuangan Untuk Penanganan Pandemi Corona Virus Disease 2019 (Covid- 19) dan/atau Dalam Rangka Menghadapi Ancaman Yang Membahayakan Perekonomian Nasional dan / atau Stabilitas Sistem Keuangan Menjadi Undang-Undang

Program PEN yang merupakan salah satu bagian dari Program pemerintah bertujuan untuk melindungi, mempertahan dan meningkatkan kemampuan ekonomi para pelaku usaha dalam menjalankan usaha ini dilaksanakan dengan prinsip : (1) asas keadilan social, (2) sebesar-besarnya kemakmuran rakyat, (3) mendukung pelaku usaha, (4) menerapkan kaidahkaidah yang penuh kehati-hatian, serta tata kelola yang baik, transparan akseleratif, adil dan akuntabel sesuai dengan ketentuan perundangundangan, (5) tidak menimbulkan moral hazar, dan (6) adanya pembagian biaya dan risiko antar pemangku kepentingan sesuai tugas dan kewenangan masing-masing. 16

Khusus tentang penjaminan, PP NO. 23/2020 menyebutkan bahwa pemerintah dapat melakukan penjamin secara langsung maupun melalui badan usaha yang ditunjuk. Badan usaha yang ditunjuk. Melalui PMK No. 71/2020 Badan Usaha yang ditunjuk tersebut adalah PT. Jaminan Kredit Indonesia (Jamkrindo) dan PT. Asuransi Kredit Indonesia (Askrindo). Penetapan PT. JAMKRINDO dan PT Askrindo melalui Keputusan Menteri Keuangan No. 305/KMK.08.2020 tanggal 26 Juni 2020 tentang Penugasan PT. Askrindo yang merupakan bagian dari implementasi PMK No. 71/2020 tentang tata cara Penjaminan Pemerintah melalui Badan Usaha Penjaminan. Sebagai Badan Usaha yang memberikan penjamin terhadap pelaksanaan program ini merupakan bagian dari peran lembagi jaminan dalam konteks adalah jaminan penanggungan / immaterial.

Adapun pokok-pokok materi yang diatur dalam PMK No. 71 /PMK.08/2020 antara lain :

1. Dukungan fasilitas pembayaran Imbal Jasa Penjaminan (IJP) yang dibayarkan Pemerintah kepada Pelaku Usaha UMKM ;

2. Proses dan tata cara permohonan penjaminan, pengajuan klaim penjaminan serta pembayaran klaim;

3. Kriteria penerima jaminan serta kriteria terjamin ;

\footnotetext{
${ }^{16} \mathrm{https} / / / w w w . d j k n . k e m e n k e u . g o . i d / b e r i t a / b a c a / 20594 / T e r b i t k a n-P P-232020-$

Pemerintah-Tetapkan-Empat-Opsi-Kebijakan-Pemulihan-Ekonomi-Nasional.html , diakses 28.01.2021
} 
4. Penugasan PT Jamkrindo dan PT Askrindo untuk melaksanakan Penjaminan Pemerintah;

5. Dukungaan Pemerintah dalam rangka penugasan PT. Jamkrindo dan atau PT. Askrindo;

6. Ketentuan mengenai pembayaran imbal jasa penjaminan ;

7. Penganggaran dalam pelaksanaan penjaminan pemerintah; dan,

8. Pengawasan, pemantauan dan evaluasi atas penugasan kepada PT. Jamkrindo dan atau PT. Askrindo

Dapat dilihat secara prinsip hal ini merupakan bagian dari penerapan prinsip program PEN butir (4) penerapan kaidah-kaidah kehatiaan, serta tata kelola yang baik, transparan akseleratif, adil dan akuntabel sesuai dengan ketentuan perundang-undangan, serta prinsip (6) adanya pembagian biaya dan risiko antar pemangku kepentingan sesuai tugas dan kewenangan masing-masing. Artinya dengan keterlibatan Badan Usaha sebagai penjamin merupakan bagian langkah mitigasi risiko terhadap program - program lain yang diterapkan, misalnya penerapan program memberikan tambahan kredit (pembiayaan) modal kerja kepada UMKM. Fungsi jaminan dalam program ini adalah memberikan jaminan apabila dalam pelaksanaan pemberiaan tambahan kredit ternyata Debitur penerima kredit tidak mampu menyelesaikan kewajiban pembayaran kewajiban atas kreditnya. Pola yang diterapkan adalah ; 1) memberikan jaminan pinjaman modal kerja kepada UMKM untuk pengajuan baru atau tambahan modal kerja dalam rangka restrukturisasi dengan maksimal total plafond pinjaman sebesar RP $10 \mathrm{M}, 2$ ) jaminan, maksimal dijamin sebesar $80 \%$ dari sisa plafon plus tunggakan bunga atau maksimal sebesar nilai plafon pinjaman.3) pola penutupannya dapat dilakun dengan cara CAC dan CBS dengan jaminan 80\%, 4) periode waktu pinjaman maksimal 3 tahun, 5) dukungan loss limit oleh pemerintah, bila klaim telah melebihi 90\% dari akumulasi Imbal Jasa Penjaminan (IJP) yang telah diterima oleh Penjamin.

Manfaat yang diterima dengan program Penjaminan ini bagi bagi Lembaga penyalur keuangan adalah 1) memberikan kepastian pembayaran bagi Lembaga keuangan yang telah menyalurkan KMK PEN apabila debitur gagal bayar, 2) mengurangi risiko yang dihadapi Lembagai Keuangan penyalur KMK PEN atas pemberian kredit kepada Debitur KMK PEN dan bagi penerima pembiayaan manfaat terbesarnya adalah Akses Pembiayaan yang lebih besar dari sumber pembiayaan tanpa harus memperhatikan jaminan kebendaan yang terbatas. Dalam melaksanakan penjaminan terhadap UMKM, Lembaga Penjaminan menggunakan dua pola yaitu Contional Automatic Cover (CAC) dan Case by Case (CBC). ${ }^{17}$

${ }^{17}$ Untoro Perry Warjiyo, Default Risk Dan Penjaminan Kredit UKM, Buletin Ekonomi Moneter dan Perbankan, Maret 2005 
Sejak juli 2020 hingga 28 september 2020, kedua perusahaan BUMN yang telah ditetapkan sebagai Badan Usaha Penjamin telah menjamin KMK PEN Senilai Rp 6.65 triliun. Penjaminan yang diberikan melalui perbankan tersebut diberikan kepada 13.175 debitur UMKM diseluruh Indonesia. ${ }^{18}$ Adakpun mekanisme penjaminan yang dilakukan adalah dengan cara sebagai berikut :

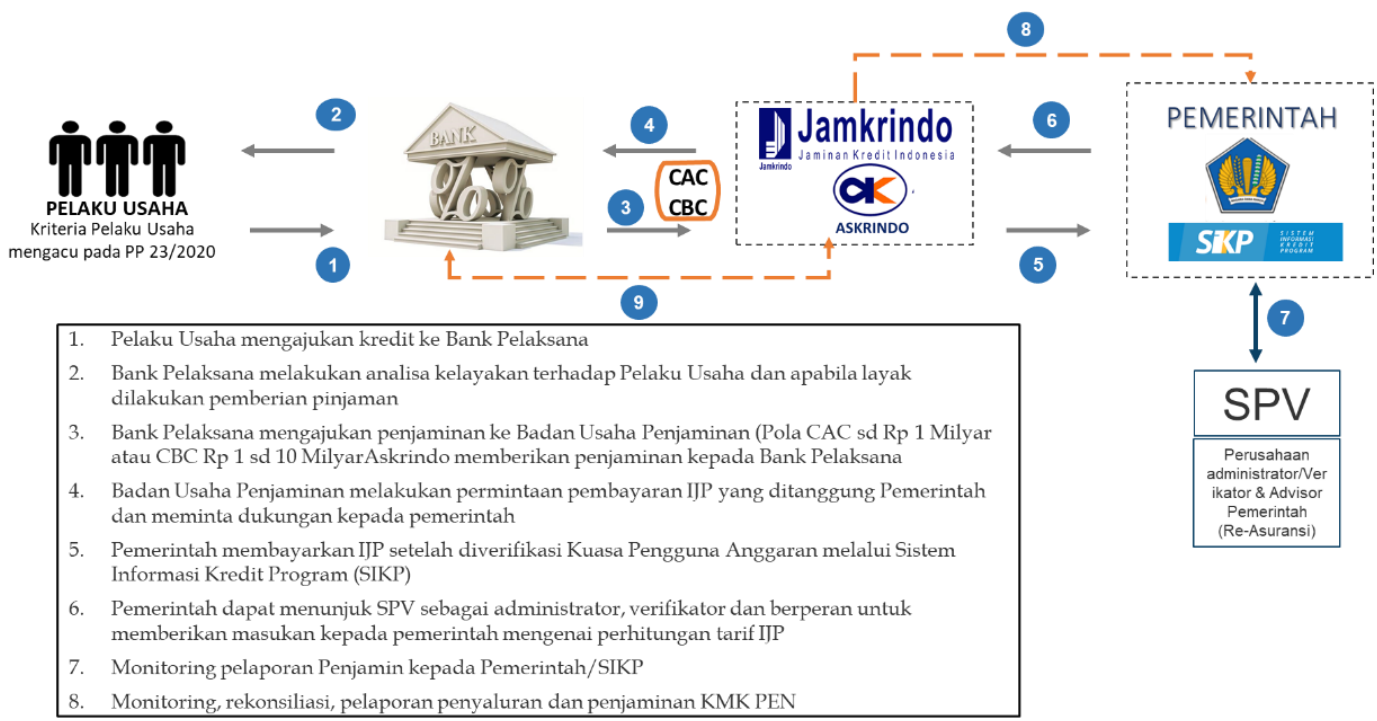

Gambar 4 : mekanisme penjaminan program PEN

Gambaran tersebut mencerminkan bahwa program penjaminan ini adalah program yang memang bertujuan untuk memberikan stimulus kepada Debitur dalam hal ini adalah UMKM sebaimana yang ditentukan dalam PP 23/2020 dilindungi dengan program jaminan yang Imbalan Jasa Penjaminannya (IJL) dibayar oleh pemerintah dan Badan Usaha Penjamin pun diberikan dukungan berupa stimulus loss limit (bila klaim melebihi \% tertentu dari IJL, pemerintah akan berkontribusi kembali).

\section{Kedudukan Notaris dalam Proses Hukum Jaminan}

Berkembangnya hukum jaminan, tidak lagi hanya tertumpu pada jaminan yang bebentuk kebendaan. Hal ini menuntut Profesi Notaris harus lebih adaptif. Walaupun Notaris tetap harus berpegang teguh pada ketentuan Pasal 15 UU No 2 tahun 2014 tentang Jabatan Notaris, Notaris berwenang untuk membuat akta autentik atas semua perbuatan, perjanjian dan ketetapan yang diharuskan oleh Peraturan Perungan-undangan, menjamin kepastian tanggal pembuatan akta, menyimpan akta dan memberikan Salinan atau kutipan akta, sepanjang pembuatan akta itu tidak ditugaskan atau

18 https://keuangan.kontan.co.id/news/hingga-28-september-penjaminan-pen-olehaskrindo-dan-jamkrindo-rp-665-triliun, diunduh 01 Februari 2021 
dikecualikan kepada pejabat lain atau orang lain yang ditetapkan oleh Undang-Undang. ${ }^{19}$ Selain itu notaris juga berwenang pula :

1. Mengesahkan tanda tangan dan menetapkan kepastian tanggal surat dibawah tangan dengan mendaftar dalam buku khusus (legalisasi);

2. Membukukan surat dibawah tangan dengan mendaftar dalam buku khusus;

3. Membuat kopi dari asli surat dibawah tangan berupa Salinan yang memuat uraian sebagaimana ditulis dan digambarkan dalam surat yang bersangkutan;

4. Melakukan pengesahan, kecocokan fotokopu dengan aslinya;

5. Memberikan penyuluhan hukum sehubungan dengan pembuatan akta ;

6. Membuat akta yang berkaitan dengan pertanahan ; atau

7. Membuat akta risalah lelang.

Eksistensi Notaris dalam merumuskan perjanjian pokok yang seimbang dan benar sesuai dengan kaidah-kaidah hukum yang berlaku, memastikan semua pihak dapat memperoleh hak secara proporsional menjadikan profesi notaris mengambil peran penting dalam program Penjaminan ini. Termasuk didalamnya merumuskan perlu tidaknya bentuk perjanjian tambahan baik yang sifatnya membebankan hak berupa jaminan kebendaan atau juga dalam konteks jaminan penanggungan yang membebankan kewajiban kepada pihak ketiga (penanggung) dalam bentuk akta otentik. Artinya mau dalam bentuk jaminan yang sifatnya kebendaan dan atau jaminan penanggungan eksistensi Notaris sangat diperlukan untuk diperolehnya dokumen otentik berupa akta sebagai bentuk perlindungan Para Pihak yang terikat dalam suatu perbuatan hukum.

\section{KESIMPULAN}

Hukum jaminan adalah perjanjian yang bersifat accecoir artinya bahwa perjanjian jaminan ini merupakan perjanjian tambahan dari perjanjian pokoknya dan segala sesuatu akibat hukumnya berjalan sesuai dengan ketentuan perjanjian pokoknya. Hukum jaminan membagi jaminan dalam 2 klasifikasi, 1) jaminan umum yang meletakkan semua pemegang jaminan pada posisi sama sebagai kreditur dan ini disebut sebagai Kreditur Konkuren, (pasal 1131, 1132 BW), 2) jaminan khusus yang meletakkan pemegang jaminan memiliki hak preference (hak yang harus didahulukan). Hukum jaminan juga mengenalkan 2 kelompok jaminan yaitu jaminan kebendaan (materiil) dan jaminan perorangan (immaterial) yang dalam perkembangannya dapat berbentuk perorangan (personal guarantee) dan dapat berbentuk bandan hukum/korporasi (corporate guarantee). 
Eksistensi Hukum jaminan dalam Program PEN dimasa pandemic Covid-19, sebagaimana PP 23/2020 terlihat sebagai bentuk manefestasi dari bagian prinsip-prinsip dalam program PEN yakni prinsip (4) tentang kehatihatian dan seterusnya, dan (6) pembagian biaya dan risiko antar pemegang kepentingan. Penetapan Badan Usaha sebagai Badan Usaha Penjamin yaitu PT. JAMKRINDO dan PT. ASKRINDO. Program penjaminan ini masuk dalam ketegori jaminan immaterii/penanggungan dengan tujuan memindahkan dan atau trasfer risiko atas potensi kerugian pemerintah karena kegagalan atas penyaluran program pembiayaan terutama dalam penguatan ekonomi melalui UMKM. Terakhir akan terlihat skema penjaminan yang diberikan lebih kepada kombinasi skema penjaminan langsung dan skema penjaminan yang dilakukan oleh Badan Usaha Penjaminan yang semua pembiayaan dilakukan oleh Pemerintah.

Keberadaan Notaris dalam program PEN ini seharusnya harus dapat dioptimalkan. Peran dan wewenang attributive yang dimiliki dari impelementasi UU Jabatan Notaris menjadi bagian bentuk sarana memberikan kepastian hukum dan perlindungan dari semua stakeholder pelaksanaan program PEN ini dengan bentuk dipegangnya dokumen otentik berupa Akta.

\section{DAFTAR PUSATAKA}

\section{Buku}

Djuhaedah Hasan, 1996, Hak Tanggungan atas tanah dan implikasinya terhadap benda-benda yang berkaitan dengan tanah, Bandung, Citra Aditya Bakti

Peter Mahmud Marzuki, 2016, Penelitian Hukum Edisi Revisim Cetakan ke 12, Jakarta : Prenada Media Group

J. Satrio, 1997, Hukum Jaminan, Hak Jaminan Kebendaan Hak Tanggungan Buku I, Jakarta, Citra Aditya Bakti.

Mariam Darus Badrulzaman, 2000,, Beberapa permasalahan hukum hak jaminan, Jurnal Hukum Bisnis Volume 11, Jakarta: Yayasan Pengembangan Hukum Bisnis

Moch. Isnaeni, 2016, Pengantar Hukum Jaminan Kebendaan, Surabaya, Revka Petra Media,

Rachmadi Usman, 2016, Hukum Jaminan Keperdataan, Jakarta, Sinar Grafika,

Sri Soedewi Masjchoen Sofwan, 1985, Hukum Jaminan di Indonesia, Jakarta, BPHN

SR. Remy Syahdeini, 1999, Hak Tanggungan asas-asas ketentuanketentuan Pokok dan Masalah yang dihadapi oleh Perbankan (Suatu 
kajian mengenai Undang-undang Hak Tanggungan), Bandung, Alumni,

Salim HS, 2019, Perkembangan Hukum Jaminan di Indonesia, Depok, Rajagrafindo Persada.

Susanti Adi Nugroho, 2018, Hukum Kepailitan di Indonesia, Jakarta, Kencana,

Jurnal

Niken Prasetyawati, Tony Hanoraga, Jaminan Kebendaan Dan Jaminan Perorangan Sebagai Upaya Perlindungan Hukum Bagi Pemilik Piutang, Jurnal Sosial Humaniora, Vol 8 No.1, Juni 2015

Untoro Perry Warjiyo, Default Risk Dan Penjaminan Kredit UKM, Buletin Ekonomi Moneter dan Perbankan, Maret 2005

Alwesius, Hukum Jaminan dalam teori dan Praktek serta Implikasi Permen ATR No. 9 tahun 2019, 2019, Malang Sosialisasi Permen ATR No.. 9 tahun 2019, IPPAT Malang

\section{Artikel}

- $\quad$ https://www.feb.ui.ac.id/blog/2020/06/30/febrio-n-kacaribu-programpemulihan-ekonomi-nasional-agar-tepat-sasaran-dalam-diskusipublik-prodeep-institute/, diunduh 28 Januari 2021

- https://ekon.go.id/info-sektoral/17/89/percepat-pemulihan-ekonominasional-pemerintah-luncurkan-penjaminan-kredit-modal-kerjaumkm, diunduh 28 Januari 2021

- $\quad$ https://www.djkn.kemenkeu.go.id/berita/baca/20594/Terbitkan-PP232020-Pemerintah-Tetapkan-Empat-Opsi-Kebijakan-PemulihanEkonomi-Nasional.html, diakses 28.01.2021

- https://keuangan.kontan.co.id/news/hingga-28-september-penjaminanpen-oleh-askrindo-dan-jamkrindo-rp-665-triliun, diunduh 01 Februari 2021

\section{Undang-Undang}

UU No. 4 tahun 1998 tentang Hak Tanggungan

UU No. 4 tahun 1999 tentang Fiducia

UU No. 1 tahun 2016 tentang Penjaminan

UU No tahun 2020 tentang Penangan

UU No. 2 Tahun 2020 Tentang Penetapan Peraturan Pemerintah Pengganti Undang-undang Nomor 1 Tahun 2020 Tentang Kebijakan Keuangan Negara Dan Stabilitas Sistem Keuangan Untuk Penanganan Pandemi Corona Virus Disease 2019 (Covid- 19) dan/atau Dalam Rangka Menghadapi Ancaman Yang Membahayakan Perekonomian 
Nasional dan / atau Stabilitas Sistem Keuangan Menjadi UndangUndang

\section{Peraturan-peraturan}

PP No. 23/2020 tentang Pelaksanaan Program Pemulihan Ekonomi Nasional

PMK No. 71/2020 tentang tata cara Penjaminan Pemerintah melalui badan usaha penjaminan 